FESIEE

Fundación Emilio Soldevilla para la Investigacion y Desarrollo

\section{Management Letters / Cuadernos de Gestión}

journal homepage: http://www.ehu.eus/cuadernosdegestion/revista/es/

ISSN: 1131-6837 / e-ISSN: 1988-2157

\title{
The mediating role of personnel training between innovation and performance: Evidence from the German pharmaceutical industry
}

\section{El rol mediador de la formación de la mano de obra entre la innovación y el rendimiento empresarial: evidencia en el sector farmacéutico alemán}

\author{
Julen Castillo-Apraiz ${ }^{*}$ Jesús Matey De Antonio ${ }^{a}$ \\ a Economía Financiera II (Economía de la Empresa y Comercialización), Facultad de Ciencias Económicas y Empresariales, Universidad del País Vasco/ \\ Euskal Herriko Unibertsitatea UPV/EHU, Bilbao (Spain) - jesus.matey@ehu.eus
}

* Corresponding author: Economía Financiera II (Economía de la Empresa y Comercialización), Facultad de Ciencias Económicas y Empresariales, Universidad del País Vasco/Euskal Herriko Unibertsitatea UPV/EHU, Avda. Lehendakari Agirre 83, 48015 Bilbao (Bizkaia), Spain - julen.castillo@ehu.eus - http://orcid.org/0000 000283624163

\section{A R T I C L E I N F O}

Received 11 July 2018,

Accepted 17 February 2020

Available online 31 July 2020

DOI: $10.5295 /$ cdg. 180990 jc

JEL CODE: O31, M539

\begin{abstract}
A B S T R A C T
Purpose - The need for companies to become more innovative has never been greater, because innovation helps them deal with a turbulent environment by providing them a sustainable competitive advantage. In this sense, it has been generally accepted that a successful innovative environment requires a welltrained work force. Nevertheless, the literature showing how personnel training drives the innovationperformance relationship in industries where innovation is a key factor is scarce, especially in high-tech industries such as the pharmaceutical industry. Thus, we build upon existing studies to contribute to the innovation and training-related literature by considering the latter as a mediating variable between innovation and business performance. Hence, we aim to assess the impact of innovation on performance, and bring new insights into the innovation-performance link by including training as a variable that drives the aforementioned relationship.

Design/methodology - We apply the partial least squares structural equation modeling technique to a sample of German pharmaceutical firms. The data were collected in mid-2014 by means of a computerassisted telephone interviewing (CATI) procedure. As a result, 200 valid responses were obtained from CEOs.

Findings - First, this study demonstrates that both innovation and personnel training have a significant, positive impact on performance. Second, the results suggest that training personnel does indeed positively mediate the innovation-performance link. Hence, our study helps explain how innovation effectively translates into greater levels of performance.

Originality / value - We answer calls to clarify about the innovation-personnel training relationship to generate greater levels of performance in turbulent environments. Furthermore, we assess this fact in the pharmaceutical industry, where paradoxically there is a lack of studies within the aforementioned framework.
\end{abstract}

Keywords: innovation, pharmaceutical industry, personnel training, performance, mediation, IPMA. 


\section{R E S U M E N}

Objetivo - La necesidad de innovación que tienen hoy en día las empresas nunca fue mayor, dado que la innovación les ayuda a enfrentarse a entornos turbulentos, proporcionándoles una ventaja competitiva sostenible. En este sentido, la comunidad científica defiende que un entorno innovador exitoso necesita de una mano de obra bien formada. No obstante, existe un gap en la literatura a la hora de analizar cómo la formación de la mano de obra impulsa el efecto positivo de la innovación sobre el rendimiento empresarial en entornos donde la innovación es clave, sobre todo en sectores altamente tecnológicos como es el caso del sector farmacéutico. Basándonos en estudios previos, nos apoyamos en la literatura que estudia la innovación y la formación de la mano de obra y consideramos ésta última como una variable que media la relación innovación- rendimiento empresarial. Así, valoramos el impacto de la innovación sobre el rendimiento empresarial y adquirimos nuevas percepciones sobre la relación innovación-rendimiento empresarial incluyendo la formación como una variable que impulsa dicha relación.

Diseño / metodología - Aplicamos una técnica de modelización de ecuaciones estructurales partial least squares (PLS-SEM) sobre una muestra de empresas farmacéuticas alemanas. Los datos fueron obtenidos a mediados del año 2014 por medio del procedimiento computer-assisted telephone interviewing (CATI). Se obtuvieron 200 respuestas válidas de CEOs.

Resultados - En primer lugar, el estudio demuestra que tanto la innovación como la formación de la mano de obra tienen un efecto positivo y significativo sobre el rendimiento empresarial. En segundo lugar, se demuestra que efectivamente la formación de la mano de obra tiene un efecto mediador sobre la relación innovación- resultados empresariales. Así, nuestro trabajo ayuda a explicar el mecanismo mediante el cual la innovación se transforma eficazmente en un mayor rendimiento empresarial.

Originalidad / valor - Arrojamos luz sobre la relación innovación-formación de la mano de obra a la hora de generar altos niveles de resultados empresariales en entornos turbulentos. Además, analizamos esta circunstancia en el sector farmacéutico, un sector en el que paradójicamente existe una escasez de literatura científica en la materia.

Palabras clave: innovación, industria farmacéutica, formación de la mano de obra, rendimiento empresarial, mediación, IPMA. 


\section{INTRODUCTION}

As the world becomes increasingly competitive, companies are under significant pressure to enhance business performance. In this sense, innovation is undoubtedly one of the key performance drivers that can provide a sustainable competitive advantage for businesses, and hence improve their performance (e.g., Subramaniam and Youndt 2005; Beugelsdijk 2008; Kraśnicka et al. 2018; Kuncoro and Suriani 2018). Accordingly, innovation has become a way of life for many businesses and is indispensable in contemporary organizations (Yeh-Yun Lin and Yi-Ching Chen 2007; Huang et al. 2016; Ortiz-Villajos and Sotoca 2018). In fact, in the new hypercompetitive environment that companies are facing, achieving higher levels of innovation might prove to be the only path to survival, especially in high-tech industries such as the pharmaceutical industry (Xu 2015; Castillo-Apraiz et al. 2020b).

The concept of innovation is a broad topic (Dadfar et al. 2013; Calabrò et al. 2019). Innovation gives companies greater flexibility and enables them to protect themselves against unstable scenarios, helping them to seek out new opportunities (March 1991; Posen and Levinthal 2012; Zhang et al. 2014; Arzubiaga et al. 2019) and better exploit those that already exist (Huang et al. 2016; Arzubiaga et al. 2019). However, few studies analyze the influence of personnel training as a mediating variable between innovation and company performance (see Barba-Aragón 2014). It is important to examine this relationship, because personnel training is another key element supporting productivity and profitability (Blandy et al. 2000; Lyons 2019), and successful overall performance in several settings (e.g., find a meta-analysis in Tharenou et al. 2007; Dimovski et al. 2008; Ryu and Lee 2016).

We suggest that innovation has a positive influence on both performance and personnel training at a globallevel. Furthermore, we suggest that the knowledge and skills of an organization's workforce mediates the impact of innovation on performance. Analyzing the mediation effect of personnel training between innovation and performance proves to be especially important in industries such as the pharmaceutical industry, where there is a shortage of qualified staff in specific $R \& D$ areas (Frietsch and Neuhäusler 2015), and where innovation is considered to be the very essence of the industry (Bower and Whittaker 1993). We test the hypotheses using PLS-SEM on data from a sample of pharmaceutical firms.

Therewith, we contribute to extant literature in two ways. First, we reinforce the idea that innovation is one of the key performance drivers. Second, and more important, we demonstrate that personnel training has a positive impact on performance and is a relevant factor that enables innovation to translate into a better performance. In doing so we answer calls to clarify about the innovation-personnel training relationship to generate greater levels of innovation (De Saá-Pérez et al. 2012; Barba-Aragón 2014).

\section{LITERATURE REVIEW AND CONCEPTUAL MODEL}

\subsection{The impact of innovation on performance}

Innovation is a multi-faceted effort (Maravelakis et al. 2006) that can be defined as the generation and development of new products, services, or processes (Damanpour 1991). Different theories and academic fields - e.g., marketing theories, strategic theory, the theory of resources and capabilities - have revealed that innovation is essential for better performance and survival of firms. Hence, in recent times researchers have studied the innovation construct intensively in different settings and contexts (e.g., Arzubiaga 2019; Dziallas and Blind 2019), such as the pharmaceutical industry (García-Morales et al. 2008). In this regard, there is plenty of literature positing that innovation plays a key role in enhancing an organization's performance (e.g., Crone and Roper 2001; Li and Atuahene-Gima 2001; Jiménez Jiménez and Sanz Valle 2006; Chen and Huang 2009; Dadfar et al. 2013; Huang et al. 2016; Vladimirov 2016), effectiveness, and efficiency (Davis and Pett 2002). For example, GarcíaMorales et al. (2008) found that innovation has a positive impact on performance, especially on return on assets and market share. Nevertheless, innovation often encompasses a high level of risk and its implementation never assures successful results (LealRodríguez et al. 2015; Leal-Rodríguez and Albort-Morant 2016).

Besides productivity-related effects (see for example Guisado González et al. 2016), the positive impact of innovation on performance can be primarily explained by the fact that innovation helps companies to differentiate themselves from others (Jansen et al. 2006; Arzubiaga et al. 2019), which is key for gaining a sustainable competitive advantage (Walker 2004). Innovation is a multifaceted construct (Azar and Ciabuschi 2017) that can take many forms (Gunday et al. 2011). Leaving aside the organizational innovation - too broad in scope (Damanpour 1991), and sometimes embracing the other forms (Liao et al. 2017) - , product innovation is one of the most prolific topics. The notion of being first with proactive new products, i.e., new product development, is critical to obtaining first mover advantages (Langerak and Hultink 2005), and therefore, market superiority, especially in technology-intensive industries such as the pharmaceutical industry (Xu 2015). A large body of empirical research has investigated new product development and related factors, such as product innovation capability (Sharma and Martin 2018; Iddris 2019). Consequently, there is strong support for the positive relationship between new product development and performance (Damanpour 1991; Fagerberg et al. 2005; Lau et al. 2010; Rosenbusch et al. 2011; Sok and O'Cass 2015). The implementation of a new or significantly improved production or delivery method - process innovation - can have a more hazy effect than product innovation (Gunday et al. 2011), but it positively and significantly influences performance too (e.g., Ali et al. 2016; Tsinopoulos et al. 2018). Marketing innovation has not yet motivated a great deal of research (Medrano and OlartePascual 2016; see the overview in Grimpe et al. 2017), but it is widely accepted that developing new marketing techniques enhances firms competitiveness (Ren et al. 2009; Gupta et al. 2016) and has a positive influence on performance (Chen 2006; Hsu 2011). Hence, it is hypothesized that:

Hypothesis 1: Innovation has a positive impact on performance.

\subsection{The impact of personnel training on performance}

Training is defined as a systematic development of the competences needed by employees to perform their work 
(Dermol and Čater 2013), or as acknowledged by Manoharan et al. (2012), “(...) [it] is all about looking ahead and developing practical programmes that result in improved performance" (p. 451). Personnel training is essential for the continuous improvement of the quality of human capital (Zheng et al. 2007; Lertxundi and Landeta 2011; Garavan et al. 2019). Furthermore, personnel training is said to be one of the most important elements of human resource development (Taylor and Davies 2004; Manoharan et al. 2012; Garavan et al. 2019). Therefore, as acknowledged by Minbaeva et al. (2014), limited investments in training may result in lower levels of knowledge and skills, while training can help developing valuable human capacities, which would enhance performance (Tharenou et al. 2007).

As Dermol and Čater (2013) suggested, the success of training depends on two factors: its quality and its volume. Regarding the quality of training, researchers support the idea that with properly trained employees, the company can grow, and as employees develop, so will the company (Williams 1997). Accordingly, the right trainees should be recruited if the desired quality of training is to be achieved. In this sense, trainees must be reliable and effective (Nikandrou et al. 2009). Attention should also be paid to proper organizational incentives (Dermol and Čater 2013). Training can be formal or informal, and receiving one type is strongly correlated with the likelihood of also receiving the other ( $\mathrm{Ng} 2005)$, even though the majority of training an employee receives is normally informal (Blandy et al. 2000), which is unplanned, undocumented and largely unstructured (Smith and Hayton 1999). In any case, training should be well-designed, set up in a way that works for the specific company it was designed for (Pluta and Fugate 2009) and relevant to the job (Nikandrou et al. 2009). Regarding the volume of training, in developed countries, companies invest a lot in training (Dermol and Čater 2013), primarily in the case of larger companies (Smith and Hayton 1999; Van Smoorenburg and Van der Velden 2000). Some decades ago, training targeted only the upper levels in businesses, but nowadays the majority of employees are trained (Blandy et al. 2000; Jarvis et al. 2003). The issue of quality personnel seems not to be a matter of education, but rather of competence. Nevertheless, it is true that the ratio between the costs and benefits of training is more favorable for employees with higher levels of education (Blunch and Castro 2005). Thus, employees with low levels of education sometimes get caught in "the low-skill, bad-job trap" (Booth and Snower 1996). Related to this, Van Smoorenburg and Van der Velden (2000) raise the question about the complementarity or substitutability between education and training. Some works (e.g., Blunch and Castro 2005; Van Smoorenburg and Van der Velden 2000) demonstrate that a higher level of education does increase the probability of receiving training.

As stated by Kirkpatrick (2006), training and performance appraisals are close relatives (see also the results of metaanalysis in Tharenou et al. 2007), even when some recent studies highlight the need for rigor (Garavan et al. 2019; Kwon 2019). Moreover, firms recoup their investments in training many times over (Blandy et al. 2000).
Nevertheless, some authors raise doubt on a positive effect of personnel training on performance. For example, some argue that only low percentage of training really ends up being applied in the workplace (Axtell et al. 1997; Brown 2005; Velada and Caetano 2007). Similarly, others argue that the success of training is questionable since training is sometimes informal and unplanned (Kotey and Folker 2007).

In any case, personnel training is a key element supporting successful performance (e.g., Blandy et al. 2000; Tharenou et al. 2007; Dimovski et al. 2008; Ryu and Lee 2016), and its benefits have been widely acknowledged in the literature (PlateroJaime et al. 2017; Zheng et al. 2007). As the result of training, individual productivity improves, employee commitment to the enterprise increases, the adaptability and flexibility of the workforce is enhanced, changes in business strategy can be made (Smith and Hayton 1999) and employee loyalty to the organization may increase (Taylor and Davies 2004). These features prove to be especially important in industries such as the pharmaceutical industry, where to some extent, there is a shortage of qualified staff in specific R\&D areas (Frietsch and Neuhäusler 2015). We hypothesize on a positive relationship between personnel training and performance.

Hypothesis 2: Personnel training has a positive impact on performance.

\subsection{The mediating effect of personnel training between innovation and performance}

A successful innovative environment requires a committed and well-trained work force that is involved in innovation (Matthews 2002; Chen and Huang 2009; D'Este et al. 2014). Thus, a highly qualified workforce increases the probability of innovation (Love and Mansury 2007; Tan and Nasurdin 2011). Precisely, as acknowledged by Shefer and Frenkel (2005), in order to innovate, companies must engage highly skilled labor that is able to cope with complex technological problems, being technology-related skills especially relevant for product and/or process innovations (Gunday et al. 2011). In this sense, Li et al. (2006) defend there is a positive relationship between personnel training and technological innovation. Specifically, the adoption of new technology is an important driver for employee training, because it is vital for maintaining the absorptive capacity of innovative companies (Zheng et al. 2007), that is, their ability to value, assimilate, and apply new external knowledge (Cohen and Levinthal 1990; Lane and Lubatkin 1998). Absorptive capacity, in turn, has a positive impact on both product innovation and process innovation (Murovec and Prodan 2009; Ali et al. 2016; Solís-Molina et al. 2018). In fact, through labour flexibility, absorptive capacity has a positive impact on organizational innovation, which in turn positively impacts organizational performance (García et al. 2018; Zou et al. 2018). Similarly, training supports absorptive capacity since it is an effective way of absorbing and managing knowledge (Gray 2006; Najafi-Tavani 2018; Xie et al. 2018), and therefore is of great importance to firms competing in $\mathrm{R} \& \mathrm{D}$-intensive industries such as the biotechnology industry (Stezano and Espinoza 2019). 
Turning to our central argument, a highly qualified workforce is very important for the development of new products (Mumford 2000; Lau and Ngo 2004; Langerak and Hultink 2005; Horbach 2010). In fact, an increase in companylevel knowledge is directly associated with innovation (Jiménez Jiménez and Sanz Valle 2006), as knowledge can facilitate the successful deployment of an innovation (García-Morales et al. 2008). Concretely, both knowledge stock and knowledge flows enhance innovation (Thornhill 2006).

All in all, training investments and innovation jointly interact to positively enhance company performance. Based on the review of the existing literature, we have formulated the following hypothesis:

Hypothesis 3: Personnel training mediates the impact of innovation on performance.

\section{RESEARCH METHODOLOGY}

\subsection{Sample and data collection}

Our population consists of all the German pharmaceutical companies operating under the 2834 SIC code ( 928 companies), and we obtained their data from the Dun \& Bradstreet Database. We chose the pharmaceutical industry because innovation is considered the driving force of the industry and training of personnel is also a key element supporting the successful performance of pharmaceutical companies (Mehralian et al. 2016). We focus on firms from this one industry only to avoid differences in industry characteristics affecting the conditional performance impacts of innovation and personnel training. Concretely, we selected German pharmaceutical companies as the sample for this study, because of the strength of the industry (both in terms of number of competitors and their performance) offering us a potential to come up with a satisfactory sample size and a good worldwide benchmark.

The data were collected in mid-2014 by means of a computerassisted telephone interviewing (CATI) procedure and stratified proportional sampling of the original population. As a result, 200 valid responses were obtained from CEOs. The sample size available is appropriate in light of the low complexity of the model used (Chin 2010; Hair et al. 2016). Power analyses needed to determine the minimum sample size support this notion (Cohen 1992; Faul et al. 2007).

\subsection{Measures}

The latent variables in our study require specific items in each measurement model. Consistent with previous research, and with a focus on product, process, and marketing innovation (Gunday et al. 2011), we adapted the existing measurement scales for innovation (Dess and Davis 1984; Covin and Slevin 1989; Davis and Pett 2002; Lin et al. 2007; Gunday et al. 2011) so that the items reflect this construct best. Precisely, we assessed the efforts of firms not only to invest in new production processes but also to explore new products and continually improve existing ones, as well as an item related to the innovation in marketing techniques. Personnel training was considered a single-item construct that aims to capture personnel training at a global level. Precisely, firms were asked to what extent they insure trained personnel. We shortened the existing measurement scales proposed in prior research for the sake of the questionnaire length, which is of special importance with regard to the target of CEOs, who emphasize the privacy of information (Homburg et al. 2004). The measurement scale for performance was adapted from previous studies (e.g., Akan et al. 2006; Allen and Helms 2006). Precisely, we selected five (reflective) items related to assets, income, revenue, market share and overall performance. All measurement items stem from a questionnaire that uses 5-point Likert scales, ranking from 1 ("far below average") to 5 ("far above average").

\section{RESULTS OF THE DATA ANALYSIS}

The data analysis was performed using the partial least squares structural equation modeling (PLS-SEM) technique (find in Di Pietro et al. 2018 some PLS-SEM related advantages over other techniques), which is a useful multivariate method used in strategic management and marketing, specially due to the early phase of theorizing on the impact of both innovation and personnel training on performance (Richter et al. 2016). This modeling was conducted using the SmartPLS 3 (Ringle et al. 2015) software. Both innovation and performance were defined reflectively, as the causality emanates from the variable to the items (Podsakoff et al. 2006).

Figure 1 presents the structural model produced by the PLS analysis, which indicates the variance of the endogenous variables $\left(\mathrm{R}^{2}\right)$ and the path coefficients. Table 1 and Table 2 show the assessment of the measurement model, and Table 3 represents the structural model assessment.

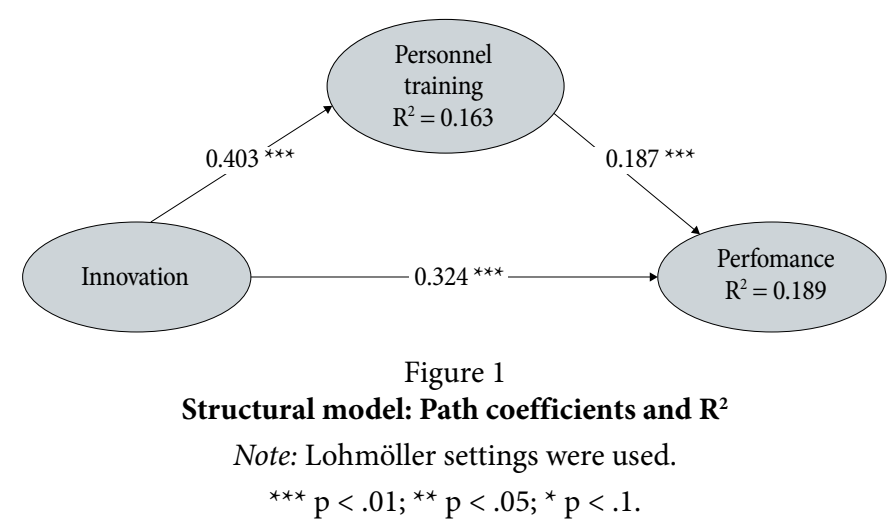

First, we assessed the measurement model (Chin 2010; Hair et al. 2016) (see Table 1 and Table 2). The assessment of the reliability of internal consistency (CR) indicated that all values were greater than 0.7 . Cronbach's $\alpha$ values were greater than or very close to 0.7 . Convergent validity was assessed by means of average variance extracted (AVE) values. All the values were greater than 0.5 . We used the HTMT criterion to reliably detect the lack of discriminant validity. In all cases, the values fell below the threshold of $85 \%$ (Kline 2011). Following the practice established by Henseler et al. (2014), we calculated the standardized root mean square residual (SRMR), which 
is 0.079 . This implies that the composite factor model fits the data fairly well, according to Browne and Cudeck (1993). To account for common method bias, survey items related to the dependent and the independent variables were separated within the survey and randomized within blocks to reduce a potential bias from their sequencing.

The next step was to evaluate the structural model (Table 3). The essential criterion for this assessment was the coefficient of determination $\left(\mathrm{R}^{2}\right)$. We concluded that the exogenous latent variables had moderate effects on performance, taking into account the research discipline and the simplicity of the model. A bootstrapping procedure was used to analyze the statistical significance of the paths. The effect size $\left(\mathrm{f}^{2}\right)$ allows the contribution of the construct to an endogenous latent variable to be assessed. To ascertain the existence of collinearity, the tolerance of each predictor construct (VIF) value was calculated and determined to be greater than 0.2 , but less than 5 (Hair et al. 2011).

Table 1

Evaluation results: Measurement model

\begin{tabular}{|c|c|c|c|c|}
\hline Constructs/indicators & Loading & $\begin{array}{l}\text { Composite } \\
\text { reliability }\end{array}$ & $\begin{array}{c}\text { Cronbach's } \\
\alpha\end{array}$ & AVE \\
\hline Innovation & & 0.804 & 0.668 & 0.511 \\
\hline $\begin{array}{l}\text {-Develop and refine } \\
\text { established products }\end{array}$ & 0.784 & & & \\
\hline $\begin{array}{l}\text {-Innovation in } \\
\text { manufacturing process }\end{array}$ & 0.638 & & & \\
\hline $\begin{array}{l}\text {-Innovation in marketing } \\
\text { techniques }\end{array}$ & 0.580 & & & \\
\hline $\begin{array}{l}\text {-New product } \\
\text { development }\end{array}$ & 0.828 & & & \\
\hline Performance & & 0.953 & 0.938 & 0.801 \\
\hline -Total asset growth & 0.925 & & & \\
\hline -Net income growth & 0.872 & & & \\
\hline $\begin{array}{l}\text {-Overall performance/ } \\
\text { success }\end{array}$ & 0.906 & & & \\
\hline -Total revenue growth & 0.876 & & & \\
\hline -Market share growth & 0.897 & & & \\
\hline
\end{tabular}

Note: $\mathrm{AVE}=$ Average variance extracted

Table 2

Discriminant validity assessment: Heterotrait-monotrait ratio of correlations

\begin{tabular}{lccc}
\hline & Performance & Innovation & Personnel training \\
\hline Performance & 1 & & \\
Innovation & 0.502 & 1 & 1 \\
Personnel training & 0.326 & 0.494 & 1 \\
\hline
\end{tabular}

Table 3

Assessment of the structural model

\begin{tabular}{|c|c|c|c|c|c|}
\hline $\begin{array}{l}\text { Endogenous } \\
\text { construct }\end{array}$ & \multicolumn{3}{|c|}{$\mathrm{R}^{2}$} & \multicolumn{2}{|l|}{$\mathrm{Q}^{2}$} \\
\hline Performance & \multicolumn{2}{|c|}{0.189} & & \multicolumn{2}{|c|}{0.148} \\
\hline $\begin{array}{l}\text { Personnel } \\
\text { training }\end{array}$ & \multicolumn{2}{|c|}{0.163} & & \multicolumn{2}{|c|}{0.159} \\
\hline Path & $\begin{array}{c}\text { Path } \\
\text { coefficient }\end{array}$ & $\begin{array}{l}\text { Collinearity } \\
\text { (VIF) }\end{array}$ & $\mathbf{f}^{2}$ & $t$-value & $\begin{array}{c}\text { Bias } \\
\text { corrected } \\
95 \% \\
\text { confidence } \\
\text { interval }\end{array}$ \\
\hline $\begin{array}{l}\text { Innovation } \rightarrow \\
\text { Performance }\end{array}$ & 0.324 & 1.194 & 0.109 & $6.531^{\star * *}$ & $\begin{array}{l}{[0.230} \\
0.423]\end{array}$ \\
\hline $\begin{array}{l}\text { Personnel } \\
\text { training } \rightarrow \\
\text { Performance }\end{array}$ & 0.187 & 1.194 & 0.036 & $3.272^{\star * *}$ & $\begin{array}{l}{[0.071 ;} \\
0.296]\end{array}$ \\
\hline $\begin{array}{l}\text { Innovation } \rightarrow \\
\text { Personnel } \\
\text { training }\end{array}$ & 0.403 & 1.000 & 0.194 & $8.627^{\star * *}$ & $\begin{array}{l}{[0.314 ;} \\
0.496]\end{array}$ \\
\hline
\end{tabular}

Note: The cross-validated redundancy measure $\left(\mathrm{Q}^{2}\right)$ is derived from the blindfolding procedure with an omission distance of 7 . The $t$-values are derived from the bootstrapping procedure with the pairwise deletion algorithm. VIF $=$ variance inflation factor.

${ }^{* * *} \mathrm{p}<.01 ;{ }^{* *} \mathrm{p}<.05 ;{ }^{*} \mathrm{p}<.1$

Our findings revealed that innovation has a positive influence on both performance (Table 3: path coefficient of $0.324 ; \mathrm{p}<.01$ ) and personnel training (Table 3: path coefficient of $0.403 ; \mathrm{p}<.01$ ). Therefore, Hypothesis 1 is supported. Similarly, personnel training also has a positive effect on performance (Table 3: path coefficient of $0.187 ; \mathrm{p}<.01$ ). Therefore, Hypothesis 2 is supported.

Finally, the mediation effect of personnel training between innovation and performance was analyzed. Since focusing on the significance of the direct relation before and after examining a mediator may be unnecessarily restrictive, we utilized the typology proposed by Zhao et al. (2010, Table 4). We concluded that there is a complementary mediation. This result (Table 4) demonstrates a significant indirect effect of personnel training on the innovation-performance path.

Table 4

Mediation

\begin{tabular}{|c|c|c|}
\hline Indirect effect & $t$-value & Type of Mediation \\
\hline $\begin{array}{l}\text { Personnel training } \\
\text { between } \\
\text { Innovation } \rightarrow\end{array}$ & $3.007^{\star * *}$ & $\begin{array}{l}\text { Complementary } \\
\text { mediation }\end{array}$ \\
\hline
\end{tabular}

Note. The t-values are derived from the bootstrapping procedure with the pairwise deletion algorithm.

${ }^{* *} \mathrm{p}<.01{ }^{* *} \mathrm{p}<.05 ;{ }^{*} \mathrm{p}<.1$

By focusing on performance, we also conducted an importance-performance matrix analysis (IPMA) to extend the 
PLS-SEM results (Höck et al. 2010; Ringle and Sarstedt 2016; Hair et al. 2019) (Table 5). This analysis shows that innovation has the highest importance, but a relatively low performance. Hence, innovation is a key factor that should be considered if performance is to be improved.

Table 5

Importance-performance matrix analysis (IPMA)

\begin{tabular}{lcc}
\hline & Importance & Performance \\
\hline Innovation & 0.443 & 53.925 \\
Personnel training & 0.164 & 72.188 \\
\hline
\end{tabular}

\section{DISCUSSION}

\subsection{Implications for theory}

The need for companies to become more innovative has never been greater. The literature traditionally highlights the importance of innovation towards gaining a competitive advantage that would enhance business performance (Vladimirov 2016). For example, the notion of being first with proactive new products, i.e., new product development, is critical to obtaining first mover advantages (Langerak and Hultink 2005), and therefore, market superiority. Accordingly, there is strong support for the positive relationship between new product development and performance (Damanpour 1991; Fagerberg et al. 2005; Lau et al. 2010; Rosenbusch et al. 2011; Sok and O'Cass 2015). In addition, personnel training is another key element supporting successful performance (Blandy et al. 2000; Tharenou et al. 2007; Dimovski et al. 2008; Ryu and Lee 2016) since it enhances organizational learning. Surprisingly, there is a lack of studies that attempt to bring these two drivers of business performance together by considering personnel training as a mediator between innovation and performance. Hence, this study contributes to enhancing the innovation-related literature by including personnel training as a significant mediator in the innovation-performance relationship. Precisely, we examined our proposed relationships in the German pharmaceutical industry.

This first contribution made by this study lies in stressing the importance of innovation in the performance. Developing new products and developing and refining established products is crucial, because it has been identified as the key to the company's success, profit and survival (Sok and O'Cass 2015). Similarly, developing marketing techniques (Chen 2006; Ren et al. 2009; Hsu 2011; Gupta et al. 2016) and processes (Ali et al. 2016; Tsinopoulos et al. 2018) positively influences performance too.

The second contribution lies in suggesting that ensuring a company has trained personnel also has a positive impact on the performance. This finding corroborates previous studies (Aw et al. 2007; Frietsch and Neuhäusler 2015; McGuirk et al. 2015), suggesting that having trained personnel is especially crucial in R\&D-intensive sectors - such as the pharmaceutical industry-. The knowledge and skills of an organization's workforce are important resources on which successful organizations invest.
Accordingly, training is a key element in disciplines such as Human Resource Development and Learning and Development (Garavan et al. 2019).

Thirdly, the results demonstrate personnel training positively mediates the innovation-performance link. Hence, personnel training is a relevant factor that enables innovation to translate into a better performance, since knowledge can facilitate the successful deployment of an innovation (García-Morales et al. 2008). All in all, in line with what was hypothesized, training investments and innovation jointly interact to positively enhance company performance.

Finally, the results of the IPMA (Höck et al. 2010; Ringle and Sarstedt 2016; Hair et al. 2019) suggest that the construct of innovation has the highest importance, but a relatively low performance as compared to personnel training. Hence, by focusing on innovation, there is certainly room for improvement regarding firms' performance in high-tech industries.

\subsection{Implications for management}

From a managerial point of view, this study also provides clear indications. As shown in the PLS-SEM results and the IPMA analysis, in turbulent and dynamic environments, practitioners should bet strongly on innovation and should rely on personnel training to enable greater performance within a successful innovative environment. We further develop our arguments.

In the pharmaceutical industry, innovation plays even a more important role than in other industries. Generally speaking, innovation is considered the driving force of the pharmaceutical industry (Malerba and Orsenigo 2015) and is the best approach for pharmaceutical companies to gain a competitive position in the global market (Lin et al. 2007). For example, despite the fact that product innovation is highly uncertain (Cooper and Kleinschmidt 1993; Damanpour et al. 2009; Leal-Rodríguez and Albort-Morant 2016), developing new products and developing and refining established products is crucial for managers, because it has been identified as the key to the company's success, profit and survival (Sok and O'Cass 2015). This holds true even when firms have abandoned such innovation activities (Tsinopoulos et al. 2019). Besides the importance of process innovation (see for example Bauer and Leker 2013; Malerba and Orsenigo 2015), product innovation and marketing innovation are key influencing factors in the biotechnology and pharmaceutical industries (Lin et al. 2007), which reinforces the idea that practitioners should bet strongly on innovation, as also shown in our IPMA analysis.

Second, managers should rely on personnel training to enable greater performance within a successful innovative environment. The likelihood of training tends to be different not only between industries in developed and developing countries (Booth 1991; Ng 2005), but also among industries themselves. In this sense, the technological intensity of each sector plays a key role. Subramanian and Zimmermann (2013) concluded that technology-intensive companies are expected to invest in training programs that provide opportunities for professional and personal development. Specifically, the adoption of new technology is an important driver for employee training, because it is vital for maintaining the absorptive capacity of innovative companies (Zheng et al. 2007). Thus, in the pharmaceutical 
industry, training plays a major role, because innovation is the very essence of the industry, and as a result, the absorptive capacity of the organization needs to be developed (Cockburn and Henderson 1998; Lane et al. 2001; Nooteboom et al. 2007; Fabrizio 2009).

\section{LIMITATIONS AND DIRECTIONS FOR FURTHER RESEARCH}

This paper is not free from limitations. First, we considered personnel training as the only variable that mediates the innovation-performance relation. Furthermore, this variable is measured by a single item. Second, only specific aspects of performance were analyzed. Third, respondents were not asked to provide objective measures. As a result, our study inevitably suffers from the normal bias associated with subjective measures. Finally, since we studied German pharmaceutical companies, it must be admitted that the path coefficients could differ significantly across different countries and sectors. Hence, since the same cause can produce different effects in specific circumstances (Ordanini et al. 2014; Wu et al. 2014), results should be extrapolated to other sectors with caution.

This study establishes new paths for further research. First, future research could include other variables that mediate the innovation-performance relationship to better explain performance. Similarly, by including moderating variables researchers could gain new insights. Second, even if the German pharmaceutical industry offers us a good worldwide benchmark, researchers could conduct similar studies in different industries and countries, with the aim of analyzing the different results. In this regard, future research might investigate how institutional characteristics affect the relations to give us a better understanding of the reasons why results differ among industries. Accordingly, associating the results with the new institutional economy (Williamson 1975; Johannessen 2008) is one way to expand the research reported here. Third, further studies should distinguish between different types of innovation and assess their impact on performance (NaranjoValencia et al. 2018; Castillo-Apraiz et al. 2020a). Similarly, instead of capturing personnel training at a global level, further studies could for example assess how personnel training within specific areas - such as R\&D - impacts performance. Fourth, analyzing the relations from within a longitudinal framework would allow a better interpretation of the results. Evaluating possible variations over time would be particularly interesting for assessing the change in the mediating effect of training on the innovation-performance relationship. Finally, further works could focus more on predictive aspects (see for example Shmueli et al. 2019; Hwang et al. 2020; Liengaard et al. 2020) or use new analytic tools such as Necessary Condition Analysis (NCA) (see for example Richter et al. 2020) to gain new insights.

\section{ACKNOWLEDGEMENTS}

We are grateful to some colleagues and the anonymous reviewers for their helpful comments and insights. We highly appreciate the financial support received from the Fundación Emilio Soldevilla para la Investigación y el Desarrollo en Economía de la Empresa (FESIDE) foundation and the Unidad de Formación e Investigación en Dirección Empresarial y Gobernanza Territorial y Social (UFI 11/51) research and training unit.

\section{REFERENCES}

Akan, O., Allen, R. S., Helms, M. M., and Spralls, S. A. I., 2006. Critical tactics for implementing Porter's generic strategies. The journal of business strategy, 27 (1), 43-53.

Ali, M., Kan, K. A. S., and Sarstedt, M., 2016. Direct and configurational paths of absorptive capacity and organizational innovation to successful organizational performance. Journal of business research, 69 (11), 5317-5323.

Allen, R. S., and Helms, M. M., 2006. Linking strategic practices and organizational performance to Porter's generic strategies. Business process management journal, 12 (4), 433-454.

Arzubiaga, U., 2019. Gobernanza corporativa y orientación emprendedora de las pymes familiares: un análisis de la influencia de la implicación familiar a distintos niveles. Cuadernos de gestión, 19 (1), 119-146.

Arzubiaga, U., Castillo-Apraiz, J., and Palma-Ruiz, J. M. 2019. Competitive advantage development in family firms by transforming entrepreneurial orientation into CSR: evidence from Spain. In Handbook of Research on Entrepreneurial Leadership and Competitive Strategy in Family Business (pp. 112-128). IGI Global.

Arzubiaga, U., Maseda, A., and Iturralde, T., 2019. Exploratory and exploitative innovation in family businesses: the moderating role of the family firm image and family involvement in top management. Review of managerial science, 13 (1), 1-31.

Aw, B. Y., Roberts, M. J., and Winston, T., 2007. Export market participation, investments in $\mathrm{R} \& \mathrm{D}$ and worker training, and the evolution of firm productivity. The world economy, 30 (1), 83-104.

Axtell, C. M., Maitlis, S., and Yearta, S. K., 1997. Predicting immediate and longer-term transfer of training. Personnel review, 26 (3), 201213.

Azar, G., and Ciabuschi, F., 2017. Organizational innovation, technological innovation, and export performance: The effects of innovation radicalness and extensiveness. International business review, 26 (2), 324-336.

Barba-Aragón, M. I., 2014. La habilidad de los directivos y su papel mediador entre formación e innovación. Revista europea de dirección y economía de la empresa, 23 (3), 127-136.

Bauer, M., and Leker, J., 2013. Exploration and exploitation in product and process innovation in the chemical industry. R\&D Management, 43 (3), 196-212.

Beugelsdijk, S., 2008. Strategic human resource practices and product innovation. Organization studies, 29 (6), 821-847.

Blandy, R., Hawke, A., Webster, E., and Dockery, A. M., 2000. Does training pay?: evidence from Australian enterprises: National Centre for Vocational Education Research.

Blunch, N.-H., and Castro, P., 2005. Multinational enterprises and training revisited: do international standards matter?: Social Protection, World Bank.

Booth, A. L., 1991. Job-related formal training: who receives it and what is it worth? Oxford bulletin of economics and statistics, 53 (3), 281294.

Booth, A. L., and Snower, D. J., 1996. Acquiring Skills: Market Failures, their Symptoms and Policy Responses: Cambridge University Press. 
Bower, D. J., and Whittaker, E., 1993. Global R\&D networks: the case of the pharmaceutical industry. Journal of industry studies, 1 (1), 50-64.

Brown, T. C., 2005. Effectiveness of distal and proximal goals as transferof-training interventions: A field experiment. Human resource development quarterly, 16 (3), 369-387.

Browne, M. W., and Cudeck, R., 1993. Alternative ways of assessing model fit. Sage focus editions, 154, 136-136.

Calabrò, A., Vecchiarini, M., Gast, J., Campopiano, G., De Massis, A., and Kraus, S., 2019. Innovation in family firms: A systematic literature review and guidance for future research. International journal of management reviews, 21 (3), 317-355.

Castillo-Apraiz, J., Arzubiaga, U., and Palma-Ruiz, J. M., 2020a. Is being conservative at home whilst taking risks abroad a suitable competitive strategy? the case of spanish family firms internationalizing to Mexico. In Entrepreneurship and Family Business Vitality (pp. 257268). Springer.

Castillo-Apraiz, J., Palma-Ruiz, J. M., and Arzubiaga, U., 2020b. Is the impact of sustainability exploration on firm economic return so obvious? the case of internationalized spanish firm operating in hightech and low-tech industries. In Sustainable Innovation: Advocating and Organizing Enterprises Consciously. Routledge.

Chen, C.-J., and Huang, J.-W., 2009. Strategic human resource practices and innovation performance-The mediating role of knowledge management capacity. Journal of business research, 62 (1), 104-114.

Chen, Y., 2006. Marketing innovation. Journal of economics \& management strategy, 15 (1), 101-123.

Chin, W. W., 2010. How to write up and report PLS analyses. In V. Vinzi, W. W. Chin, J. Henseler, and H. Wang (Eds.), Handbook of Partial Least Squares (pp. 655-690): Springer.

Cockburn, I. M., and Henderson, R. M., 1998. Absorptive capacity, coauthoring behavior, and the organization of research in drug discovery. The journal of industrial economics, 46 (2), 157-182.

Cohen, J., 1992. A power primer. Psychological bulletin, 112 (1), 155-159.

Cohen, W. M., and Levinthal, D. A., 1990. Absorptive capacity: A new perspective on learning and innovation. Administrative science quarterly, 35 (1), 128-152.

Cooper, R. G., and Kleinschmidt, E. J., 1993. Major new products: what distinguishes the winners in the chemical industry? Journal of product innovation management, 10 (2), 90-111.

Covin, J. G., and Slevin, D. P., 1989. Strategic management of small firms in hostile and benign environments. Strategic management journal, 10 (1), 75-87.

Crone, M., and Roper, S., 2001. Local learning from multinational plants: knowledge transfers in the supply chain. Regional studies, 35 (6), 535-548.

D’Este, P., Rentocchini, F., and Vega-Jurado, J., 2014. The role of human capital in lowering the barriers to engaging in innovation: evidence from the Spanish innovation survey. Industry and innovation, 21 (1), 1-19.

Dadfar, H., Dahlgaard, J. J., Brege, S., and Alamirhoor, A., 2013. Linkage between organisational innovation capability, product platform development and performance: The case of pharmaceutical small and medium enterprises in Iran. Total quality management \& business excellence, 24 (7), 819-834.

Damanpour, F., 1991. Organizational innovation: A meta-analysis of effects of determinants and moderators. Academy of management journal, 34 (3), 555-590.

Damanpour, F., Walker, R. M., and Avellaneda, C. N., 2009. Combinative effects of innovation types and organizational performance: A longitudinal study of service organizations. Journal of management studies, 46 (4), 650-675.

Davis, P. S., and Pett, T. L., 2002. Measuring organizational efficiency and effectiveness. Journal of management research, 2 (2), 87-97.
De Saá-Pérez, P., Díaz-Díaz, N. L., and Luis Ballesteros-Rodríguez, J., 2012. The role of training to innovate in SMEs. Innovation, 14 (2), 218-230.

Dermol, V., and Čater, T., 2013. The influence of training and training transfer factors on organisational learning and performance. Personnel review, 42 (3), 324-348.

Dess, G. G., and Davis, P. S., 1984. Porter's (1980) generic strategies as determinants of strategic group membership and organizational performance. Academy of management journal, 27 (3), 467-488.

Di Pietro, F., Palacín-Sánchez, M. J., and Roldán, J. L., 2018. Regional development and capital structure of SMEs. Cuadernos de gestión, 18 (1), 37-60.

Dimovski, V., Škerlavaj, M., Kimman, M., and Hernaus, T., 2008. Comparative analysis of the organisational learning process in Slovenia, Croatia, and Malaysia. Expert systems with applications, 34 (4), 3063-3070.

Dziallas, M., and Blind, K., 2019. Innovation indicators throughout the innovation process: An extensive literature analysis. Technovation, 80, 3-29.

Fabrizio, K. R., 2009. Absorptive capacity and the search for innovation. Research policy, 38 (2), 255-267.

Fagerberg, J., Mowery, D. C., and Nelson, R. R., 2005. The Oxford Handbook of Innovation. USA: Oxford University Press.

Faul, F., Erdfelder, E., Lang, A.-G., and Buchner, A., 2007. G Power 3: A flexible statistical power analysis program for the social, behavioral, and biomedical sciences. Behavior research methods, 39(2), 175-191.

Frietsch, R., and Neuhäusler, P., 2015. The development of qualification and employment structures in non-R\&D-intensive industry sectorsThe case of Germany Low-tech innovation (pp. 67-78): Springer.

Garavan, T., McCarthy, A., Sheehan, M., Lai, Y., Saunders, M. N., Clarke, N., ... and Shanahan, V., 2019. Measuring the organizational impact of training: The need for greater methodological rigor. Human resource development quarterly, 30, 291-309.

García-Sánchez, E., García-Morales, V., and Martín-Rojas, R., 2018. Influence of technological assets on organizational performance through absorptive capacity, organizational innovation and internal labour flexibility. Sustainability, 10 (3), 770.

Garcia-Morales, V. J., Matias-Reche, F., and Hurtado-Torres, N., 2008. Influence of transformational leadership on organizational innovation and performance depending on the level of organizational learning in the pharmaceutical sector. Journal of organizational change management, 21 (2), 188-212.

Gray, C., 2006. Absorptive capacity, knowledge management and innovation in entrepreneurial small firms. International journal of entrepreneurial behavior \& research, 12 (6), 345-360.

Grimpe, C., Sofka, W., Bhargava, M., and Chatterjee, R., 2017. R\&D, Marketing Innovation, and New Product Performance: A Mixed Methods Study. Journal of product innovation management, 34 (3), 360-383.

Guisado González, M., Vila Alonso, M., and Guisado Tato, M., 2016. Innovación, capacidad productiva, formación en el puesto de trabajo y productividad. Cuadernos de gestión, 16 (2), 77-92.

Gunday, G., Ulusoy, G., Kilic, K., and Alpkan, L., 2011. Effects of innovation types on firm performance. International journal of production economics, 133 (2), 662-676.

Gupta, S., Malhotra, N. K., Czinkota, M., and Foroudi, P., 2016. Marketing innovation: A consequence of competitiveness. Journal of business research, 69 (12), 5671-5681.

Hair, J., Hult, G., Ringle, C., Sarstedt, M., Castillo-Apraiz, J., Cepeda Carrion, G., and Roldán, J., 2019. Manual de partial least squares structural equation modeling (pls-sem): Terrassa, Spain: OmniaScience. 
Hair, J. F., Ringle, C. M., and Sarstedt, M., 2011. PLS-SEM: Indeed a silver bullet. Journal of marketing theory and practice, 19 (2), 139-152.

Hair Jr, J. F., Hult, G. T. M., Ringle, C., and Sarstedt, M., 2016. A primer on partial least squares structural equation modeling (PLS-SEM): Sage Publications.

Henseler, J., Dijkstra, T. K., Sarstedt, M., Ringle, C. M., Diamantopoulos, A., Straub, D. W., . . . Calantone, R. J., 2014. Common beliefs and reality about PLS: Comments on Rönkkö and Evermann (2013). Organizational research methods, 17 (2), 182-209.

Hock, C., Ringle, C. M., and Sarstedt, M., 2010. Management of multipurpose stadiums: Importance and performance measurement of service interfaces. International journal of services technology and management, 14 (2-3), 188-207.

Homburg, C., Krohmer, H., and Workman, J. P., 2004. A strategy implementation perspective of market orientation. Journal of business research, 57 (12), 1331-1340.

Horbach, J., 2010. The Impact of Innovation Activities on Employment in the Environmental Sector-Empirical Results for Germany at the Firm Level. Jahrbücher für nationalökonomie und statistik, 230 (4), 403-419.

Hsu, Y., 2011. Design innovation and marketing strategy in successful product competition. Journal of business \& industrial marketing, 26 (4), 223-236.

Huang, K.-E., Wu, J.-H., Lu, S.-Y., and Lin, Y.-C., 2016. Innovation and technology creation effects on organizational performance. Journal of business research, 69 (6), 2187-2192.

Hwang, H., Sarstedt, M., Cheah, J. H., and Ringle, C. M., 2020. A concept analysis of methodological research on composite-based structural equation modeling: bridging PLSPM and GSCA. Behaviormetrika, 47 (1), 219-241.

Iddris, F., 2019. Innovation capability and product innovation performance: the case of low-tech manufacturing firms. European business review, 31 (5), 646-668.

Jansen, J. J., Van Den Bosch, F. A., and Volberda, H. W., 2006. Exploratory innovation, exploitative innovation, and performance: Effects of organizational antecedents and environmental moderators. Management science, 52 (11), 1661-1674.

Jarvis, P., Holford, J., and Griffin, C., 2003. The Theory \& Practice of Learning: Psychology Press.

Jiménez Jiménez, D., and Sanz Valle, R., 2006. Innovación, aprendizaje organizativo y resultados empresariales. Un estudio empírico. Cuadernos de economía y dirección de la empresa 29, 31-55.

Johannessen, J.-A., 2008. Explaining institutional change: aspects of an innovation in the new institutional economy. Kybernetes, 37 (1), 20-35

Kirkpatrick, D. L., 2006. Training and performance appraisal-are they related? Improving employee performance through appraisal and coaching, 60 (9), 44-45.

Kline, R. B., 2011. Principles and Practice of Structural Equation Modeling. New York, NY: Guilford publications.

Kotey, B., and Folker, C., 2007. Employee training in SMEs: Effect of size and firm type-Family and nonfamily. Journal of small business management, 45 (2), 214-238.

Kraśnicka, T., Głód, W., and Wronka-Pośpiech, M., 2018. Management innovation, pro-innovation organisational culture and enterprise performance: testing the mediation effect. Review of managerial science, 12 (3), 737-769.

Kuncoro, W., and Suriani, W. O., 2018. Achieving sustainable competitive advantage through product innovation and market driving. Asia pacific management review, 23 (3), 186-192.

Kwon, K., 2019. The long-term effect of training and development investment on financial performance in Korean companies. International journal of manpower, 40 (6), 1092-1109.
Lane, P. J., and Lubatkin, M., 1998. Relative absorptive capacity and interorganizational learning. Strategic management journal, 19 (5), 461-477.

Lane, P. J., Salk, J. E., and Lyles, M. A., 2001. Absorptive capacity, learning, and performance in international joint ventures. Strategic management journal, 22 (12), 1139-1161.

Langerak, F., and Hultink, E. J., 2005. The impact of new product development acceleration approaches on speed and profitability: Lessons for pioneers and fast followers. IEEE transactions on engineering management, 52 (1), 30-42.

Lau, A. K., Tang, E., and Yam, R., 2010. Effects of supplier and customer integration on product innovation and performance: Empirical evidence in Hong Kong manufacturers. Journal of product innovation management, 27 (5), 761-777.

Lau, C. M., and Ngo, H. Y., 2004. The HR system, organizational culture, and product innovation. International business review, 13 (6), 685-703.

Leal-Rodríguez, A. L., and Albort-Morant, G., 2016. Linking Market Orientation, Innovation and Performance: An Empirical Study On Small Industrial Enterprises In Spain. Journal of small business strategy, 26 (1), 37-50.

Leal-Rodríguez, A. L., Eldridge, S., Roldán, J. L., Leal-Millán, A. G., and Ortega-Gutiérrez, J., 2015. Organizational unlearning, innovation outcomes, and performance: The moderating effect of firm size. Journal of business research, 68 (4), 803-809.

Lertxundi, A., and Landeta, J. 2011. The moderating effect of cultural context in the relation between HPWS and performance: An exploratory study in Spanish multinational companies. The international journal of human resource management, 22 (18), 3949-3967.

Li, Zhao, Y., and Liu, Y., 2006. The relationship between HRM, technology innovation and performance in China. International journal of manpower, 27 (7), 679-697.

Li, H., and Atuahene-Gima, K., 2001. Product innovation strategy and the performance of new technology ventures in China. Academy of management journal, 44 (6), 1123-1134.

Liao, S.-s., Chen, C.-C., Hu, D.-c., Chung, Y.-C., and Liu, C.-L., 2017. Assessing the influence of leadership style, organizational learning and organizational innovation. Leadership \& organization development journal, 38 (5), 590-609.

Liengaard, B., Sharma, P. N., Hult G., T. M., Jensen, M. B. Sarstedt, M, Hair, J. F., and Ringle, C. M., 2020. Prediction: coveted, yet forsaken? Introducing a cross-validated predictive ability test in Partial Least Squares Path Modeling. Decision sciences, in press.

Lin, M.-Q., Lin, W., and Pao, C.-H., 2007. The effects of technology transfer, marketing strategy and innovation strategy on the operating performance of the biotech/pharmaceutical industry in Taiwan. International journal of electronic business management, 5 (2), 138-151.

Love, J. H., and Mansury, M. A., 2007. External linkages, R\&D and innovation performance in US business services. Industry and innovation, 14 (5), 477-496.

Lyons, E., 2019. The impact of job training on temporary worker performance: Field experimental evidence from insurance sales agents. Journal of economics \& management strategy, 1-25.

Malerba, F., and Orsenigo, L., 2015. The evolution of the pharmaceutical industry. Business history, 57 (5), 664-687.

Manoharan, T., Muralidharan, C., and Deshmukh, S., 2012. A composite model for employees' performance appraisal and improvement. European journal of training and development, 36 (4), 448-480.

Maravelakis, E., Bilalis, N., Antoniadis, A., Jones, K. A., and Moustakis, V. 2006. Measuring and benchmarking the innovativeness of SMEs: A three-dimensional fuzzy logic approach. Production planning \& control, 17 (3), 283-292.

March, J. G., 1991. Exploration and exploitation in organizational learning. Organization science, 2 (1), 71-87. 
Matthews, J., 2002. Innovation in Australian small and medium enterprises: contributions from strategic human resource management. Asia pacific journal of human resources, 40 (2), 193-204.

McGuirk, H., Lenihan, H., and Hart, M., 2015. Measuring the impact of innovative human capital on small firms' propensity to innovate. Research policy, 44 (4), 965-976.

Medrano, N., and Olarte-Pascual, C., 2016. The effects of the crisis on marketing innovation: An application for Spain. Journal of business \& industrial marketing, 31 (3), 404-417.

Mehralian, G., Nazari, J. A., Rasekh, H. R., and Hosseini, S., 2016. TOPSIS approach to prioritize critical success factors of TQM: evidence from the pharmaceutical industry. The TQM journal, 28 (2), 235-249.

Minbaeva, D., Pedersen, T., Björkman, I., Fey, C. F., and Park, H. J., 2014. MNC knowledge transfer, subsidiary absorptive capacity and HRM. Journal of international business studies, 45 (1), 38-51.

Mumford, M. D., 2000. Managing creative people: Strategies and tactics for innovation. Human resource management review, 10 (3), 313-351.

Murovec, N., and Prodan, I., 2009. Absorptive capacity, its determinants, and influence on innovation output: Cross-cultural validation of the structural model. Technovation, 29 (12), 859-872.

Najafi-Tavani, S., Najafi-Tavani, Z., Naudé, P., Oghazi, P., and Zeynaloo, E., 2018. How collaborative innovation networks affect new product performance: Product innovation capability, process innovation capability, and absorptive capacity. Industrial marketing management, 73, 193-205.

Naranjo-Valencia, J. C., Naranjo-Herrera, C. G., Serna-Gómez, H. M., and Calderón-Hernández, G., 2018. The Relationship Between Training And Innovation In Companies. International journal of innovation management, 22 (02), 1850012.

Ng, Y. C., 2005. Training determinants and productivity impact of training in China: A case of Shanghai. Economics of education review, 24 (3), 275-295.

Nikandrou, I., Brinia, V., and Bereri, E., 2009. Trainee perceptions of training transfer: An empirical analysis. Journal of european industrial training, 33 (3), 255-270.

Nooteboom, B., Van Haverbeke, W., Duysters, G., Gilsing, V., and Van den Oord, A., 2007. Optimal cognitive distance and absorptive capacity. Research policy, 36 (7), 1016-1034.

Ordanini, A., Parasuraman, A., and Rubera, G., 2014. When the recipe is more important than the ingredients: A qualitative comparative analysis (QCA) of service innovation configurations. Journal of service research, 17 (2), 134-149.

Ortiz-Villajos, J. M., and Sotoca, S., 2018. Innovation and business survival: A long-term approach. Research policy, 47 (8), 1418-1436.

Platero-Jaime, M., Benito-Hernández, S., and Rodríguez-Duarte, A., 2017. The moderator effect of training in the adoption of ICT in microenterprises. Cuadernos de gestión, 17 (2), 87-108.

Pluta, P. L., and Fugate, T., 2009. Effective training. Journal of GXP compliance, 13 (3), 10-13.

Podsakoff, N. P., Shen, W., and Podsakoff, P. M., 2006. The role of formative measurement models in strategic management research: Review, critique, and implications for future research. Research methodology in strategy and management, 3 (1), 197-252.

Posen, H. E., and Levinthal, D. A., 2012. Chasing a moving target: Exploitation and exploration in dynamic environments. Management science, 58 (3), 587-601.

Ren, L., Xie, G., and Krabbendam, K., 2009. Sustainable competitive advantage and marketing innovation within firms: A pragmatic approach for Chinese firms. Management research review, 33 (1), 79-89.

Richter, N. F., Sinkovics, R. R., Ringle, C. M., and Schlägel, C. 2016. A critical look at the use of SEM in international business research. International marketing review, 33 (3), 376-404.
Richter, N. F., Schlaegel, C., Bakel, M. V., and Engle, R. L., 2020. The expanded model of cultural intelligence and its explanatory power in the context of expatriation intention. European journal of international management, 14 (2), 381-419

Ringle, C. M., and Sarstedt, M., 2016. Gain more insight from your PLSSEM results: The importance-performance map analysis. Industrial management \& data systems, 116 (9), 1865-1886.

Ringle, C. M., Wende, S., and Becker, J.-M., 2015. Smartpls 3. Hamburg: SmartPLS.

Rosenbusch, N., Brinckmann, J., and Bausch, A., 2011. Is innovation always beneficial? A meta-analysis of the relationship between innovation and performance in SMEs. Journal of business venturing, 26 (4), 441-457.

Ryu, H.-S., and Lee, J.-N., 2016. Innovation patterns and their effects on firm performance. The service industries journal, 36 (3-4), 81-101.

Sharma, S. O., and Martin, A. 2018. Re-thinking and re-operationalizing product innovation capability: A review, critique and extension of dynamic capability view using theoretical triangulation. European business review, 30 (4), 374-397.

Shefer, D., and Frenkel, A., 2005. R\&D, firm size and innovation: An empirical analysis. Technovation, 25 (1), 25-32.

Shmueli, G., Sarstedt, M., Hair, J.F., Cheah, J.H., Ting, H., Vaithilingam, S., and Ringle, C.M., 2019. Predictive model assessment in PLS-SEM: Guidelines for using PLSpredict. European journal of marketing, in press.

Smith, A., and Hayton, G., 1999. What drives enterprise training? Evidence from Australia. International journal of human resource management, 10 (2), 251-272.

Sok, P., and O'Cass, A., 2015. Examining the new product innovationperformance relationship: Optimizing the role of individual-level creativity and attention-to-detail. Industrial marketing management, 47, 156-165.

Solís-Molina, M., Hernández-Espallardo, M., and Rodríguez-Orejuela, A., 2018. Performance implications of organizational ambidexterity versus specialization in exploitation or exploration: The role of absorptive capacity. Journal of business research, 91, 181-194.

Stezano, F., and Espinoza, R. O., 2019. Innovation capabilities and performance of biotechnology firms. Management research: journal of the iberoamerican academy of management, 17 (4), 445-473.

Subramaniam, M., and Youndt, M. A., 2005. The influence of intellectual capital on the types of innovative capabilities. Academy of management journal, 48 (3), 450-463.

Subramanian, D., and Zimmermann, B., 2013. Training and capabilities in French firms: How work and organisational governance matter. International journal of manpower, 34 (4), 326-344.

Tan, C. L., and Nasurdin, A. M., 2011. Human resource management practices and organizational innovation: Assessing the mediating role of knowledge management effectiveness. Electronic journal of knowledge management, 9 (2), 155-167.

Taylor, R., and Davies, D. 2004. Aspects of training and remuneration in the accommodation industry: A comparison between Australian and Singaporean providers. Journal of european industrial training, 28 (6), 466-473.

Tharenou, P., Saks, A. M., and Moore, C., 2007. A review and critique of research on training and organizational-level outcomes. Human resource management review, 17 (3), 251-273.

Thornhill, S., 2006. Knowledge, innovation and firm performance in high-and low-technology regimes. Journal of business venturing, 21 (5), 687-703.

Tsinopoulos, C., Sousa, C. M., and Yan, J., 2018. Process innovation: open innovation and the moderating role of the motivation to achieve legitimacy. Journal of product innovation management, 35 (1), 27-48 
Tsinopoulos, C., Yan, J., and Sousa, C. M., 2019. Abandoning innovation activities and performance: The moderating role of openness. Research policy, 48 (6), 1399-1411.

Van Smoorenburg, M., and Van der Velden, R. K., 2000. The training of school-leavers: complementarity or substitution? Economics of education review, 19 (2), 207-217.

Velada, R., and Caetano, A., 2007. Training transfer: the mediating role of perception of learning. Journal of european industrial training, 31 (4), 283-296.

Vladimirov, Z., 2016. SME Innovations and Performance: The Mediating Role of Product Innovation. International review of entrepreneurship, 14 (2), 209-233.

Walker, R. M., 2004. Innovation and organisational performance: Evidence and a research agenda.

Williams, D. R., 1997. The frequency and perceived value of formal training in selected business firms in Pennsylvania's Lycoming and Columbia counties. Pennsylvania State University.

Williamson, O. E., 1975. Markets and Hierarchies. New York: Free Press.

Wu, P.-L., Yeh, S.-S., Huan, T.-C., and Woodside, A. G., 2014. Applying complexity theory to deepen service dominant logic: Configural analysis of customer experience-and-outcome assessments of professional services for personal transformations. Journal of business research, 67 (8), 1647-1670.
Xie, X., Zou, H., and Qi, G., 2018. Knowledge absorptive capacity and innovation performance in high-tech companies: A multi-mediating analysis. Journal of business research, 88, 289-297.

$\mathrm{Xu}, \mathrm{S}$., 2015. Balancing the two knowledge dimensions in innovation efforts: an empirical examination among pharmaceutical firms. Journal of product innovation management, 32 (4), 610-621.

Yeh-Yun Lin, C., and Yi-Ching Chen, M., 2007. Does innovation lead to performance? An empirical study of SMEs in Taiwan. Management research news, 30 (2), 115-132.

Zhang, D., Linderman, K., and Schroeder, R. G., 2014. Does the rationale for implementing quality management practices matter? The quality management journal, 21 (2), 65-77.

Zhao, X., Lynch Jr, J. G., and Chen, Q., 2010. Reconsidering Baron and Kenny: Myths and truths about mediation analysis. Journal of consumer research, 37 (2), 197-206.

Zheng, C., Hyland, P., and Soosay, C, 2007. Training practices of multinational companies in Asia. Journal of european industrial training, 31 (6), 472-494.

Zou, T., Ertug, G., and George, G., 2018. The capacity to innovate: A meta-analysis of absorptive capacity. Innovation, 20 (2), 87-121. 